\title{
Race-ing with the Times: Theatrical Exigency and Performative Politics in Trevor Nunn's Othello (1989)
}

\author{
Susan L. Fischer \\ Bucknell University \\ sfischer@bucknell.edu
}

\begin{abstract}
An almost beat-by-beat re-viewing and re-reading of the temptation scene in Trevor Nunn's 1989 National Theatre production of Othello registered a need to query whether the director's decision to cast a (black) opera singer rather than a (Shakespearean) actor in the demanding role of Othello had been misguided. This view presupposes that theatrical exigency - the development of a dramatic action and on-stage situation - would be highlighted over the contingency of performative politics, however vital contemporary attention to cultural matters of "inauthenticity" and "political correctness" may be regarded.
\end{abstract}

This cannot be, By no assay of reason: 'tis a pageant To keep us in false gaze. (Othello, 1.3.18-20)

This "false gaze", highlighted by Marjorie Garber in Shakespeare After All, is the foundation of the "cause" (5.2.1), the fallacious offense of adultery Othello prefers not to name. The "false gaze" pervades the entire play, even if the phrase is used among secondary characters in an early dramatic dialogue: "the audience will see, again and again, other staged 'pageants', produced like this one to delude the onlooker, to 'keep us in false gaze" (Garber, 2004: 590). The unanswered questions of Othello criticism and of the play — its characters and actors, on the page and on stage - are analogously 
put when Garber, in Shakespeare and Modern Culture (2008: 164, 177, 176) invokes an alternative to Joseph Jastrow's classic double view of the rabbit/duck from Gestalt psychology, to wit: the double focus of a black zebra with white stripes/white zebra with black stripes, not to mention the notion of a crossroads, a "zebra crossing" in Britain (a pedestrian crossing signaled by broad black-and-white stripes on the road), and to push the application to its extreme limit, a "zebra in a zebra crossing". Garber's (2008: 177) point is that "the play is itself the most elusive and maddening of optical and conceptual - illusions, figure and ground constantly exchanging places". She posits the play's black/white issues in these terms:

The first kind of reading — Othello as a black zebra with white stripes - would view the play as about the referent, blackness, as underlying "reality" toward which critical attention should turn. The second kind of reading - Othello as a white zebra with black stripeswould point instead toward the question of representation, of blackness as a theatrical (and political and cultural) effect, and thus as a template and touchstone for response on and off stage. (2008: 164, emphasis in original)

The play's history of performance and reception by audience and (scholarly) critics has often confounded these two perspectives. Garber continues:

Another way of phrasing this would be to say that one kind of reading is historical, cultural, and referential, and the other kind is symbolic or allegorical. The second kind of reading has, over time, focused on questions like "evil", where "black" and "white" are terms related to truth and falsehood, clarity and confusion, morality and amorality, and so on. ... [S]ome interpretations, and some stagings, of Othello have used the black/white theme as the surface structure of another kind of allegory, one that might concern itself with virtue and vice, say, or with triangulated jealousy. These readings cannot be dismissed as mere evasions of the "real" subject; at different times some topics (like sexuality or religion) have been as "loaded" as race, contributing to the "tragic loading" of this play. (2008: 164-65, emphasis in original)

If Edward Wilson (1965: 63) wrote in 1946 in respect of Calderón de la Barca's La vida es sueño [Life's a Dream] that "to attempt a new interpretation" of that play may well appear "a rash undertaking", then it is an even more awesome task to attempt to render yet another reading of Othello, which is veritably a "cultural seismograph, measuring "the force of gender, racial, or class upheavals" (Kolin, 2002: 1), on the page as well as on stage. ${ }^{1}$ Thus, it was thought that our task would be all the more manageable were we to undertake yet one more "reading" of a performance text of the play, insofar as it would be circumscribed by the specific choices of director, actors, set and sound designers, etc. in a particular cultural moment and milieu. More particularly, it was believed that Trevor Nunn's militaristic and claustrophobic production of 1989 with the Royal Shakespeare Company, initially staged in the restrictive confines of Stratford-upon-Avon's The Other Place, would work well to explore the ways in which onlookers on and off stage could be kept moving between figure and ground in perpetual "false gaze". 2 
Why Nunn's production? The following factors stood out:

- It featured a virtually uncut performance text readily available for re-viewing, transference from one medium to another notwithstanding.

- It cast a black actor to play Othello (the first black actor to play the part at Stratford since Paul Robeson had played it thirty years before): an opera singer with experience at Glyndebourne but without experience of ever playing Shakespeare; as Robert Smallwood (1990: 113) notes, "in a curious, almost disturbing way, this seemed to fit the role rather aptly, the alien among the Venetians, the black opera singer among the white Shakespeareans".

- It offered proverbial attention to "business" and props - giving the action a "rare plausibility" (Billington, 1989: 34) - in an elusive, nineteenth-century (Edwardian) period setting; reviewers' guesswork regarding the military milieu varied from the Franco-Prussian War, to the American Civil, to the Crimean.

- It gave greater weight, not just to the Othello-Desdemona (Willard White-Imogen Stubbs) relationship, but also to the Desdemona-Emilia (Zoë Wanamaker) connection and to Emilia's dramatic "history" with Iago ("remembered" in Carol Rutter's [2001] incisive reading of both play and production).

- It presented an innocent and loving, yet impetuous and forthright, Desdemona who struggled for her life with emotional intensity and showed unselfish concern for others.

- It depicted a seamless, if perverse, balance of intimate and strategic behaviors in the personage of Iago (Ian McKellen) enacted, not as evil incarnate with actions that sprang from a "motiveless malignity", as Coleridge once put it, but as a psychotic, buttoned up, military man capable of inspiring trust with men through gestures of physicality (e.g., clasping Roderigo's [Michael Grandage] hands and carefully arranging his hair over a head bandage after the drunken brawl in 2.3); and with the "captain's captain" (e.g., "compassionately" consoling and caressing her when she was distressed in 4.2) - even as he was "a personality warped and eaten up by jealousy, by a contemptuous sense of his own ability to wield power, a longing to do so - and to stop others from doing so" (Smallwood, 1990: 114). For McKellen, it was an identifiable case of sexual jealousy, insofar as Iago's soliloquies told the audience: "I don't like Cassio, and I hate Othello, because I think they have fucked my wife. Even if they haven't, it feels as if they have" (Gore-Langton, 1990: 37 , emphasis in original).

- It would enable the exploration of a potentially underdeveloped side of an Othello production, insofar as it had missed, in the words of consummate critic Michael Billington (1989: 34) "the sound we long for in tragedy; the agonised cry of a cornered human soul the "sense of unpredictable danger that should. . . plunge you into the stark, primitive world of tragedy".

- Its deliberate reduction of the play's global framework by underplaying the VenetianTurkish conflict interrogated the extent to which criticism on the origin of sexual, racial, and religious anxieties in Elizabethan society - e.g., Stephen Greenblatt's (1980, 2005) new historical view of the "improvisation of power", and the implications of St. Paul's discussion of marriage in Ephesians 5.28-32, whereby love "unsettles the orthodox schema of orthodox obedience" (240); and Ania Loomba's (2002) exploration of the interrelatedness of race and gender in early modern drama and, more specifically, the ways in which Othello "fuses various contemporary discourses of Moorish 'difference' which 
circulated in Shakespeare's times" (109) —might inform or illuminate directorial choices and/or audience response in a modern production.

These points were meant to serve as ground for honing in on the production's temptation scene, insofar as it is a blueprint for Iago's masterful manipulation of language "to insinuate, to imply, to pull out of people's imaginations the dark things that are already there"; and, more particularly, to "[dupe] Othello with his own fantasies as bait" (Garber, 2004: 606). Nevertheless, an almost beat-by-beat re-viewing and rereading of the scene registered a need to query whether the director's decision to cast a (black) opera singer rather than a (Shakespearean) actor in the demanding role of Othello had, in fact, been misguided. This view, of course, presupposes that theatrical exigency - the development of a dramatic action and on-stage situation - would be highlighted over the contingency of performative politics, however vital contemporary attention to cultural matters of "inauthenticity" and "political correctness" may be regarded. It also presumes that, as Garber posits:

All "race" in the plays is enacted, not essential, and it is enacted, not to reveal the supposed "truth" about Shakespeare's views, whatever they may have been, but rather to develop a dramatic situation that is entirely fictive...

When we cast a black actor in the protagonist's role, we are "modernizing" the play - just as we do when we cast a woman in the role of Desdemona. (2004: 171)

That Othello achieves its effect by "concentration rather than dilation" in A. C. Bradley's (n.d.: 149) viable phrase - manifested dramatically in the restrictive atmosphere in which four of its five acts take place- was well captured in Nunn's staging; but more radically, the phrase is linked to the time pressure prevailing in the play, often described in terms of the (short) "dramatic time" of the tragic action and the (historical or long) "real time" required for the actual occurrence of the events we are asked to follow and believe in (see Granville-Barker, 1958: 24-30). The vertiginous speed of the "dramatic time" in which Othello's tragic self-deception occurs poses what the late director John Houseman (1959: 32) calls a "real problem of organization: the technical necessity of so plotting and distributing the vocal and emotional climaxes that they do not cross or interfere with each other, but move in ordered sequences along an effective and rising dramatic curve". The actor's problem is to make the most of the "Olympian" words Shakespeare has given him while "executing those intense dramatic motions which the playwright - revealing a human being in the grip of the most violent and tragic emotions - requires him to perform credibly upon the stage" (Houseman, 1959: 32). That these "titanic emotions" arise (simply) out of Iago's vindictive and poisonous lie around sexual jealousy means that the passion must be interpreted as "not merely intense and violent but also deep enough to carry the structure and supply the motive force of a major tragic work" (Houseman, 1959: 32-33).

Shakespeare chose not to break the temptation scene, not to change locations, not have Desdemona and Othello converse, not to give Othello a chance for reflection or the querying of anyone but Iago. And, in order that "we may rather feel with Othello in 
his suffering than despise him," in the words of Harley Granville-Barker, "we are speeded through time as unwittingly as he, and left little more chance for reflection" (1958: 29, emphasis in original). Almost immediately after his exit to supper with Desdemona - barely giving Emilia an opening to find the fatal handkerchief - Othello returns suffering, yet unable to resist "the poisonous fascination of Iago's insinuations" (Houseman, 1959: 34). The point, however, is that "it takes extraordinary dramatic and poetic virtuosity to keep the tension from breaking under such wrenches and ellipses; to keep us concerned and fearful over a situation which we know to be completely false" (Houseman, 1959: 34-35). It is partly because there is no "cause" for suspicion that Iago's lie and Othello's reaction to it are so tragically fatal; to seek a logical explanation with causes and motivations is finally to risk destroying "the main, soaring arch of the play's structure" (Houseman, 1959: 35).

The question then becomes: To what extent did the Othello in Nunn's production enact a dramatically believable transformation from a black man who was a "valiant" (1.3.49) warrior and leader of men, a courtly and civilized servant of the Venetian state, one judged by the Duke of Venice to be "far more fair than black" (1.3.291), into a veritable stereotype of himself — “jealous, volatile, and eventually remorselessly, murderously violent" (Mangan, 1991: 159); into a subverted stereotype of "a paradoxically noble Moor, and a senex who is not silly but sympathetic", one who, if noble, is also capable of "manifesting precisely those elements which he most seeks to deny in himself - the violence and sexual obsession of the stock Moor, the gullibility and jealousy of the stock senex" (161)? In his review of the production, Billington poses the problem of White's performance in theatre terms thus:

[At] some point, we wait for Othello's wracking anguish and what F. R. Leavis called his "heroic self-dramatization" to break out; and in Mr. White's performance this never quite happens. He is superb in the opening scenes: a majestic war-lord. . . He is very moving at the close when he pathetically ransacks Desdemona's dressing table and allows his great rich bass to sing the blues.

But in the central scenes of the play you wait impatiently for the thunderbolt to explode and for any real sign of mental torment: even a line like "I'll tear her all to pieces" is delivered with chair-bound temperance. . .

Ultimately, this has an effect on Ian McKellen's Iago: in the central scenes he is, to vary the animal metaphor, like a matador in search of an angry bull. (1989: 34)

The central scene of 3.3 will now be the focus of attention.

$*$

On a simple set with slatted, sun-bleached boards screening an upper level (from which Othello would look down on Iago's and Cassio's conversation about Bianca in 4.1, in a veritable "pageant" intended to keep the onlooker "in false gaze"), and a sandy floor below (over which a carpet was spread for the Venetian scenes), Iago stopped dead in his tracks as he observed Desdemona offering her hand to Cassio (Sean Baker), who 
plied it gallantly with a kiss. Iago's protracted "Oooh" (not "Ha!"), "I like not that" (3.3.34), though seemingly meant for himself, was registered by Othello, en passant, as he engaged in strategic writing and sorting of papers, chairbound at a camp table. Desdemona and Othello's playfulness in respect of the lieutenant's suit not being "denied" (rendered symbolically "bittersweet" by a glass of tart, sugarless lemonade wife offered husband) ended in a passionate embrace and kiss. One could sense the reactions of this Emilia and this Iago as each watched separately: her envy (especially since she was playing a psychologically battered wife in a marriage on the brink of collapse), and his jealous mind preparing to feign an innocent reaction. Othello's fullness of feeling for Desdemona shone forth on "I will deny thee nothing" (3.3.83); and the nature and quality of his passionate love were clear on "Excellent wretch!. . . / But I do love thee", without any visible sign of his envisioning "perdition" and "chaos" (3.3.91-93).

Iago's reinsertion of Cassio's name, and his reiteration of questions and phrases (3.3.94ff), did not pique this Othello. Nor did the general's conversational tone change in querying the "echoing" in the ensign's "monster"-laden thought process (3.3.110); he appeared to be guided by a desire to form opinions upon facts, and not upon innuendos. He seemed to be aroused by some feeling for the first time on "What dost thou mean?" (3.3.157); he raised his eyebrows on "he that filches from me my good name" (3.3.162); and his voice deepened on "By heaven, I'll know thy thoughts" (3.3.164, emphasis added): thoughts, then, seemed to provide the key to entering into Othello's mind. IagoMcKellen, attempting to pick up on this slight change in Othello-White, inserted a pregnant pause after "O beware, my lord, of jealousy!" before continuing with "It is the green-eyed monster which doth mock / The meat it feeds on. .." (3.3.167-69); his voice "seemed" to crack emotively on "Good God, the souls of all my tribe defend / From jealousy" (3.3.177-78). Othello, though gripped, was disciplined and controlled in his protestations that he was not easily "jealous" (3.3.179ff). Even when Iago became precise and blunt in urging Othello for the first time to "look to [his] wife", this general sat back in amused incredulity and returned to his paperwork. There was a bit of nervous laughter when Iago invoked Brabantio's thought of "witchcraft" with regard to Desdemona's love (3.3.214). If Othello's feelings were intensifying, his equanimity prevailed despite Iago's efforts to paint his spirits as "a little dashed", or to see him as being "moved"; he held to his belief that "Desdemona's honest" $(3.3 .218,221,228)$. Throughout this sequence, Othello seemed on guard against any rush of feeling, though his discomfiture was becoming apparent. The brusque "Farewell" (3.3.242) that followed the request for Iago to "set on his wife to observe" (3.3.244) undoubtedly reflected Othello's shame, as did the curt "Leave me" (3.3.244). Did we feel he was confronted with something more than he could manage, beyond his capacity for discipline and clear thought? This spectator did not.

During Iago's brief absence, the focus was solely on Othello: he did lose control for a moment as he crumpled the paper he was writing on and asked quietly, "Why did I marry?" (3.3.245). Upon re-entering, Iago spoke at a quickened pace as he glimpsed intermittently at the piece of ocular proof of the general's discomfiture - a smoothed 
out crumpled paper, which a large hand attempted to cover. Othello got up out of his chair — for the first time - when Iago mentioned his "wife" (cf. "lady", 3.3.254); though there were changes in his emotional state in his first sustained soliloquy, he displayed no real suffering in speaking of his love "gone", and how his "relief / Must be to loathe her" (3.3.271-72). Nor did he show visible agony on "O curse of marriage" (3.3.272) but maintained a level of strong speech throughout. When he saw Desdemona enter, his fears dissipated; he covered his face with his hands on "If she be false, ... I'll not believe it" (3.3.282-83), to dispel his imaginings? or to hide his hardly perceptible distress? He responded to her, not as an image of falseness but of purity, half smiling as she tried to bind his head with that fateful, little handkerchief, which he (prophetically) let fall to the ground.

That Desdemona did not yet appear disturbed revealed that no one had witnessed any beginning to Othello's disturbance. His visible torment following the interval (taken after Desdemona had retraced her steps, ironically, to retrieve only a stop watch and not the napkin) showed he was changing with Iago's "poison" (3.3.328): he bellowed -incongruously, given his habitual sedentary position? — on "Avaunt! Be gone! Thou hast set me on the rack" (3.3.338). Was the emotional discharge in this Othello the realization of his terrible sense of loss, the agony that that his love could not be forsaken? The angry bull that McKellen's Iago-"matador" was allegedly looking for had been unleashed (Billington, 1989: 34), as White's Othello attempted vehemently to "indicate" the conflict in feelings and thoughts.

This Othello exploded on "Farewell the neighing steed" (3.3.354), ripped up the military papers in his folder and, on "Jove's dread clamours", banged the table with his fists; still shackled to his chair, he pushed everything to the floor on "Farewell: Othello's occupation's gone" (3.3.360). ${ }^{3}$ Unhappily, the effect of this raw (re)action was more histrionic (i.e., qualitative) than evocative. The cool question voiced by this perversely punctilious Iago — "Is't possible? my lord"? (3.3.361) — as he gathered up the scattered papers - only intensified Othello's ferment; restraint was gone. As many Othellos are wont, White seized McKellen by the throat on "Villain", and pinned him to the ground on "give me the ocular proof" (3.3.363). Then began a chase and, on "so prove it" (3.3.367), Iago grabbed a garden chair in self-defense, as if he were the aforesaid "matador". Othello sought again to strangle Iago on "If thou dost slander her" (3.3.371); the latter held onto a column, crumpled military papers in hand. Only after Iago had freed himself from the general's grip, and feigned giving up his office by thrusting the contents of his satchel on the table (the detail was memorable), was there a momentary reprieve.

Othello, apparently feeling compunction for his violence, stood with Iago in intimate tête-à-tête; one could sense his being swayed by the alternate current of belief and doubt on the "honesty" of wife and ensign (3.3.387-88). Iago-McKellen's hypocritically sincere manner was alarmingly convincing in offering the general, in response to his request to be "satisfied" (3.3.396), an image of his wife being "topped" (3.3.399). If this image should have dealt a terrible blow, this Othello's mouthing of "Death and damnation" showed no intensity, though his fiery eyes bulged as he 
commanded, "Give me a living reason she's disloyal" (3.3.412). McKellen's tale of "imputation and strong circumstances" (3.3.409) began as the two sat in chairs before the camp table. But the tale seemed to be melted into thin air, leaving not a rack behind, insofar as White rather imploded on "O monstrous! monstrous!" (3.3.428); and his "I'll tear her all to pieces" had the force of a casual tête-à-tête reaction - the "chairbound temperance" which Billington (1989: 34) sensed and lamented. Iago mentioned the "handkerchief / Spotted with strawberries" (3.3.437-38) en passant as he offhandedly gathered up the papers strewn on the ground; Othello, hearing that "it speaks against her with the other proofs" (3.3.444), ran to the back wall and pounded it childishly with his fists. His uninspired puffing upward on "All my fond love thus do I blow to heaven" (3.3.447), and then collapsing — hardly a reaction "great of heart" (5.2.359) — did not connote intense mental torment at feeling the loss of his love. The rising passion and rage that should / could dominate the stage as "black vengeance" peaked on the page was conspicuously absent in performance. There was no real sense that this Othello had been transformed by murderous thoughts of "blood, blood, blood" (pronounced on his knees). Still kneeling and displaying his massive hands while rendering the eight-line Pontic sea simile, he appeared to be imploding, rather than exploding with the force of floodgates opening (as did, for example, Olivier). ${ }^{4} \mathrm{He}$ raised his arms as Iago knelt solemnly at his side in a similar pose to take the formal pact of revenge; they rose and faced one another on Othello's insipid "I greet thy love" (3.3.472). Iago kissed his victim's hand in an expression of eternal fidelity, clasped it on Othello's "Now art thy my lieutenant" (3.3.481), and then swore with blood-chilling simplicity, "I am your own forever" (3.3.482) — as the scene shifted to Desdemona's desperate search for her handkerchief in the trash.

We return now to the critical question of why, "if White had "dignity, power, handsomeness and a richly musical voice", he lacked "a sense of mental torment" (Hurren, 1989). Part of the answer lies in the actor's unfamiliarity with how Shakespeare's verse works, and his inability "to get help from" it (Barton, 1984: 25). If the effect of White's "roaring some of the briefer lines of verse" was "riveting" when set "on the rack", finally "the phrasing of all his main speeches [was] leaden" (Edwards, 1989).

Another reason why this Othello's inner agony did not get to some of us may lie in the simple fact that, as Aristotle advised, acting is doing, not emoting:

Tragedy is an imitation, not of men, but of action and of life, and life consists in action, and its end is a mode of action, not quality. Now character determines men's qualities, but it is by their actions that they are happy or the reverse. (1948: 9, emphasis added)

This not to say that the actor's performance will not be emotionally charged, but that he will not "play the emotion directly"; he will evoke it: "The emotion which the actor experiences is a result of other things he does. The direct playing of an emotion 
(imitating the external manifestations of the emotion) produces 'quality-acting,' which we usually call 'ham"” (Rockwood, 1966: 44, emphasis in original). Whether one follows the James-Lange theory which posits that emotional experience is largely due to the experience of bodily changes, or its opposite, that physiological changes are caused by emotions (collectively known as the Cannon-Bard theory of emotion), for the actor it only matters that the two factors - the mental apperception of a stimulus and the corresponding physical manifestation — work together:

The poor actor indicates to the audience the physical results of the emotion he is supposedly feeling, and short-cuts the mental process. He leaves out the vital why of the emotional experience. . . . The actor, then, must know what his action is. He must physically do it, and he must know why he is doing it. (Rockwood, 1966: 45, emphasis in original).

It would seem, then, that White merely did the cliché things which showed mental agony rather than evoking it. More particularly, if Iago had manipulated Othello into being consumed by jealousy at the end of the temptation scene, White's operatic virtuosity resulted in a largely unmoving experience. In theatre terms the actor's playing the quality of emotion, rather than his doing actions truthfully for a purpose, kept (some) onlookers "in false gaze", only somewhat filled with "horror and anger" - if finally not purged with "pity and terror" in Granville-Barker's (1958: 100) distinctionarguably wondering, as did one (re)viewer in respect of another (dull) enactment of the eponymous character, "What [was] all the fuss about?" (Wine, 1984: 12). Theatrical exigency or performative politics? There's the rub.

\section{Notes}

1. Lena Cowen Orlin (2004: 1) summarizes the trajectory of critical thinking about the play in the late twentieth century, from feminist criticism to new historicism, to cultural materialism, to poststructuralism, to postcolonialism, to Othello in public culture: "The play registers all the concerns of the newly politicized readings of the last decades: gender, power, sexuality, race. It was a key text in the works that introduced poststructuralist theory to the interpretation of English literature of the Renaissance. As a play that survives in multiple versions, including a quarto printing of 1622 and the Folio printing of 1623, it participates in debates about authorial revision, scribal corruption and textual transmission. It has a lively record on stage and screen as in criticism, and this performance history intersects urgently with the continuing legacies of empire and enslavement. The play's broadest plot outlines remain sufficiently recognizable that it informs popular understandings of sensational current events". Alternatively, Lois Potter (2002) provides a composite view of the play's stage legacy from actor's to director's theatre. It looks at the two leading male roles, and to a lesser extent the heroine, in pre-twentiethcentury theatre; explores a "transitional era" when the consensus about the three characters' "real" natures began to be questioned; and then discusses productions as a whole when (following Margaret Webster's landmark staging of 1943-44, with Paul Robeson in the title role) "directorial control affected the interpretation of all the play's characters" (Potter, 2002: 21). Potter's (2002: 185) observation that, in the late twentieth century, critics were "not only 
focusing on issues of race, class and gender but attempting to negotiate their competing demands for attention" has clear implications for the play's staging.

2. For critical commentary on Nunn's production, see Billington (1989: 34); Smallwood (1990: 110-14); Potter (2002); Rutter (2001: 142-77); Vaughan (1994: 217-32).

3. In contrast, Laurence Olivier's polemical Othello of 1964 (directed by John Dexter at London's National Theatre) began "to pace, turning his head sharply like a lion listening". The farewell to his occupation was climactic, with the words roared "as pure, wounded outcry": "he hurled back his head until the ululating tongue showed pink against the roof of his mouth like a trumpeting elephant's". And as Othello turned beast, Iago "shrunk beside him, clinging to his shoulder like an ape, hugging his heels like a jackal" (Bryden, 1964).

4. It was noted (Illustrated London News: 1964) that the 1964 performance "grows and rages in its desperate flood as the lines, unpunctuated now and magnificently vowelled observe Olivier's treatment of the reiterated ' $\mathrm{O}$ ' - swell forward to the Propontic and the Hellespont. Then, suddenly there is the isolation, the yearning, the agonized recollection on the two words 'humble love.' Again the flood beats down everything before it: 'Til that a capable and wide revenge swallow them up". Moreover, according to Bryden (1964), at "By yond marble heaven" (3.3.463), Olivier "tore the crucifix from his neck, . . . and, crouching forehead to the ground, made his 'sacred vow' in the religion which caked Benin's altars with blood".

\section{References}

Aristotle (1948): On Poetry and Music. Trans. S. H. Butcher. New York: Bobbs-Merrill. Barton, John. (1984): Playing Shakespeare. New York and London: Methuen.

Billington, Michael (26 August 1989): Othello. Guardian [London]: 34.

Bradley, A. C. (n.d.): Shakespearean Tragedy. Lecture V: Othello. Greenwich, Connecticut: Fawcett, 147-72.

Bryden, Ronald (3 May 1964): Othello. Observer [London].

Edwards, Christopher (2 September 1989): Othello. Spectator [London].

Garber, Marjorie (2004): Shakespeare After All. New York: Anchor/Random House.

Garber, Marjorie (2008): Shakespeare and Modern Culture. New York: Anchor/Random House.

Gore-Langton, Robert (1 February 1990): “A Round Unvarnished Tale”. The Listener: 36-37.

Granville-Barker, Harley. (1958): Preface to Othello. Princeton: Princeton University Press.

Greenblatt, Stephen (1980, 2005): "The Improvisation of Power". In Renaissance SelfFashioning: From More to Shakespeare. $2^{\text {nd }}$ ed. Chicago: University of Chicago Press, 222254.

Houseman, John (1959). "Comments on Producing Othello. Othello". In The Laurel Shakespeare. New York: Dell, 22-35.

Hurren, Kenneth (27 August 1989): Othello. Mail on Sunday [London].

Illustrated London News (2 May 1964).

Kolin, Philip C. (2002): "Blackness Made Visible: A Survey of Othello in Criticism, on Stage, and on Screen". In "Othello": New Critical Essays. New York and London: Routledge, 1-87.

Leavis, F. R. (1952): "Diabolic Intellect and the Noble Hero: or The Sentimentalist's Othello". In The Common Pursuit. London: Chatto \& Windus, 136-59.

Loomba, Ania (2002): "Othello and the Racial Question". In Shakespeare, Race, and Colonialism. London: Oxford University Press, 91-111. 
Mangan, Michael (1991): A Preface to Shakespeare's Tragedies. London and New York: Longman.

Orlin, Lena Cowen (2004): “Othello”: New Casebooks. New York: Palgrave/Macmillan.

Othello (1990): Dir. Trevor Nunn. Perf. Ian McKellen, Imogen Stubbs, Zoë Wanamaker, Willard White. Image Entertainment.

Othello (1965): Dir. Stuart Burge. Perf. Frank Finlay, Laurence Olivier, Joyce Redman, Maggie Smith. Warner Bros.

Potter, Lois. (2002): Shakespeare in Performance: 'Othello'. Manchester and New York: Manchester University Press.

Rockwood, Jerome (1966): The Craftsmen of Dionysus: An Approach to Acting. New York: Scott, Foresman.

Rutter, Carol (2001): "Remembering Emilia: Gossiping Hussies, Revolting Housewives". In C. Rutter, ed., Enter the Body: Women and Representation on Shakespeare's Stage. Abingdon, UK: Routledge, 142-77.

Shakespeare, William (1996): Othello. E. A. J. Honigmann, ed. London: Arden Shakespeare.

Smallwood, Robert (Spring 1990): "Shakespeare on Stage: Shakespeare at Stratford-uponAvon, 1989 (Part I)". Shakespeare Quarterly 41(1): 101-14, 110-14.

Wilson, Edward (1965): "On La vida es sueño". In B. W. Wardropper, ed., Critical Essays on the Theatre of Calderón. New York: New York University Press, 63-89.

Wine, Martin L. (1994): Othello: Text \& Performance. London: MacMillan.

Vaughan, Virginia Mason (1994): “Othello for the 1990s: Trevor Nunn's 1989 Royal Shakespeare Company Production". In V. M. Vaughan, "Othello": A Contextual History. Cambridge: Cambridge University Press, 217-32. 